\title{
RETENTION EFFICIENCY OF VEGETATIVE FILTER STRIPS FOR NITROGEN IN DANJIANGKOU RESERVOIR AREA, CENTRAL CHINA
}

\author{
EFEKTYWNOŚĆ ZATRZYMYWANIA AZOTU \\ PRZEZ PASY FILTRÓW WEGETACYJNYCH \\ W OBSZARZE ZBIORNIKA DANJIANGKOU, CHINY ŚRODKOWE
}

\begin{abstract}
To investigate the retention efficiency and mechanism of nitrogen of Vegetative filter strips (VFSs) in the Danjiangkou Reservoir area, simulated runoff discharging experiments were carried out in a new-established Bermuda VFS. The results showed that the Bermuda VFS reduced 73.1-86.1\% of surface runoff through infiltration. The outflow rate of runoff increased first and then became stable with time. The concentration reduction rates $(C R R s)$ and load reduction rates $(L R R s)$ of $\mathrm{NH}_{3}-\mathrm{N}$ increased initially and then decreased with the increase of inflow concentration. The average CRRs and $L R R s$ of $\mathrm{NH}_{3}-\mathrm{N}$ in three treatments ranged 66.1-90.3\% and 90.0-96.7 \%, respectively. The concentration reduction of $\mathrm{NH}_{3}-\mathrm{N}$ was primarily achieved by soil adsorption. The optimal inflow concentration of $\mathrm{NH}_{3}-\mathrm{N}$ for the optimum $C R R$ was between 0.65 and $3.52 \mathrm{mg} / \mathrm{dm}^{3}$. The $C R R s$ and LRRs of $\mathrm{NO}_{3}-\mathrm{N}$ fluctuated between 6.8-14.0\% and 72.0-77.9 \% in three treatments. The concentration reduction of $\mathrm{NO}_{3}-\mathrm{N}$ was primarily achieved by plant uptake and soil microbe assimilation. The optimal inflow concentration of $\mathrm{NO}_{3}-\mathrm{N}$ for optimum $C R R$ exceeded $6.78 \mathrm{mg} / \mathrm{dm}^{3}$. The $C R R s$ and LRRs of TN increased with the increase of inflow concentrations. The average $C R R s$ in the low, moderate and high treatments reached 9.7, 14.8 and $27.4 \%$, respectively, and the average $L R R s$ reached 72.1, 74.3 and $81.2 \%$, respectively. The optimal inflow concentration of TN for optimum $C R R$ exceeded $10.21 \mathrm{mg} / \mathrm{dm}^{3}$. The study showed that Bermuda grass can retain nitrogen in runoff efficiently and should be promoted around the Danjiangkou reservoir.
\end{abstract}

Keywords: vegetative filter strips, inflow concentration, retention efficiency, non-point source nitrogen pollution, retention mechanism, infiltration

\section{Introduction}

As the ongoing water crisis in China became too severe to be ignored, water shortage and increasing water pollution have gained soaring attention by decision-makers and the public [1]. Cross-basin water transfer is a common manner to optimize allocating regional water resources, and source water quality is of crucial importance to water transfer project

\footnotetext{
${ }^{1}$ Key Laboratory of Arable Land Conservation (Middle and Lower Reaches of Yangtze River), Ministry of Agriculture, Huazhong Agricultural University, Wuhan 430070, China

${ }^{2}$ Changjiang Water Resource Protection Institute, Yangtze River Water Resource Commission, Wuhan 430051, China

*Corresponding author: jzchen@mail.hzau.edu.cn
} 
[2]. Reservoir water is one of the main water-transfer source and the water pollution control is receiving increasing attention by society $[3,4]$. Reservoir water quality is regulated by a number of factors including urbanization, meteorological and hydrological factors, industrial and agricultural waste etc. Therefore, the policy makers are facing difficulty in managing the quality of this water [5,6]. The Danjiangkou Reservoir is the only water source for the South-to-North Water Division in the Middle Route Project and has a very high requirement for water quality. Although local governments closed many industrial sewage outlets in the upriver watershed since 2000, the TN concentrations of reservoir water have been higher than the objective concentration $\left(1.0 \mathrm{mg} / \mathrm{dm}^{3}\right)$ because of the agricultural non-point pollution [7].

Vegetative filter strips (VFSs) are bands of planted or indigenous vegetation between agricultural non-point pollution sources and receiving water bodies to retain runoff and other pollutants [8-11]. The earliest research on VFSs showed that grass VFSs could reduce sediment in surface runoff effectively [12]. With non-point source pollution attracting increasing attention in the 1990's, VFSs were thoroughly studied and applied as ecological engineering measures in European and American countries [13]. VFSs improve the water quality by reducing the amount of pollutants entering surface water through infiltration, filtration, adsorption, decomposition, absorption and volatilization [14]. Pollutant reduction by VFSs is primarily through sedimentation and infiltration [15]. Sedimentation effectively retains and reduces suspended matter, sediment-bound phosphorus and particulates $[16,17]$. Infiltration is another effective retention method for reducing soluble pollutants [15]. Following infiltration, soluble nitrogen and phosphorus in runoff can be transformed and/or removed through conventional nutrient cycling processes $[18,19]$.

Several published studies have demonstrated the effectiveness of VFSs in reducing non-point pollution [20-23]. Different widths of grass VFSs (e.g. Big bluestem, Tripsacum dactyloides, Switchgrass, Tall fescue and Bromegrass) can remove over $70 \%$ of the suspended matter and $68 \%$ of particulate phosphorus, with sedimentation the primary mechanism [24-27]. Regarding soluble nutrients, the grass VFSs (e.g. Orchard grass, Tall fescue, Bermuda and Switchgrass) reduce $\mathrm{NH}_{3}-\mathrm{N}$, TN, phosphorus by 81,50 and $26 \%$, with infiltration, adsorption and absorption the primary mechanisms [11, 28-30]. To some degree, pollutant retention efficiency from runoff depends on local conditions, such as climate, soil type and topography, and plant species [8, 31-34]. To date, many studies have been published on the effectiveness of reducing non-point source pollution by VFSs of different length, or different inflow rates, or different plant species and vegetation types, but few studies have been published on the effectiveness of VFSs at different inflow concentrations of pollutants.

The objectives of this paper were to study the retention efficiencies of runoff and different types of nitrogen by a VFS in the field, to analyse retention mechanisms and changes in different types of nitrogen by a VFS, and to study the optimal inflow concentration range for the highest reduction efficiency of nitrogen using simulated runoff scouring experiments.

\section{Materials and methods}

\section{Study area}

The experiment was conducted at the shore-land of the left bank near the Danjiangkou Reservoir dam (Fig. 1). The site is in a transitional area from the north subtropical to warm 
temperate climate. This region receives an average of $800 \mathrm{~mm}$ of rainfall annually, the majority of which occurs between May and October. The average annual temperature is approximately $15.1{ }^{\circ} \mathrm{C}$. The regional vegetation is evergreen broad-leaved mingled forest. The common plants of the hydro-fluctuation belt include Black locust, Sophora viciifolia, Piemarker, Polygonum aviculare, Cogongrass and Bermuda grass, among others. The experimental site had a surface slope of $7^{\circ}$. The soil type is yellow-brown soil, which is most prevalent in the Danjiangkou Reservoir catchment area. The soil texture was silt soil with a saturated hydraulic conductivity of $33.12 \mathrm{~mm} \cdot \mathrm{h}^{-1}$. The physiochemical properties of the experimental soil is summarized in Table 1 . The vegetation of the experimental site is a Bermuda community, with a few mixed Chenopodium serotinum and Potentilla supina. Table 2 shows the physiochemical properties of the experimental plants.

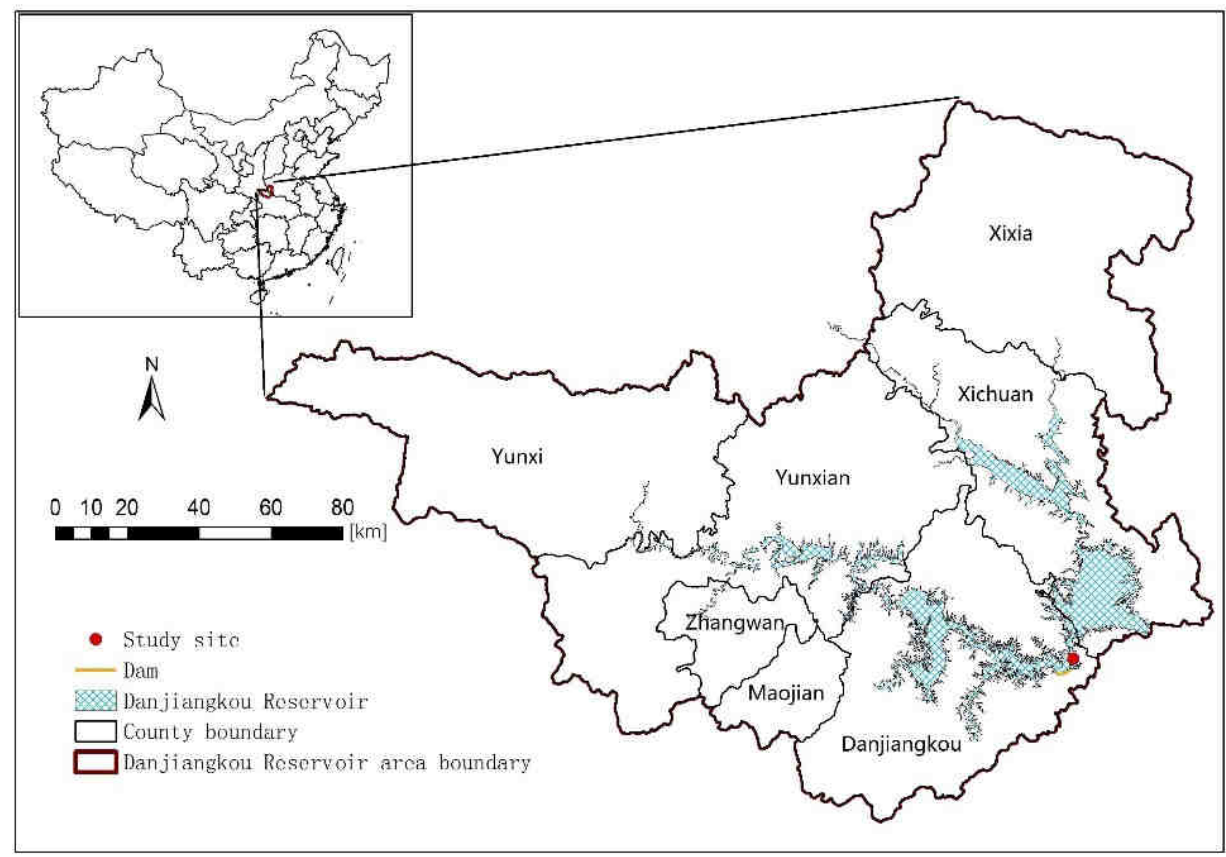

Fig. 1. The location of study site and Danjiangkou Reservoir area

Table 1

Physical-chemical properties of the experimental soil

\begin{tabular}{|c|c|c|c|c|c|c|c|c|c|c|c|}
\hline $\begin{array}{c}\text { Layer } \\
{[\mathrm{cm}]}\end{array}$ & pH [-] & $\begin{array}{c}\text { o.m. }^{\mathrm{a}} \\
{\left[\mathrm{g} \cdot \mathrm{kg}^{-1}\right]}\end{array}$ & $\begin{array}{c}\mathbf{T N}^{\mathbf{b}} \\
{\left[\mathbf{g} \cdot \mathbf{k g}^{-1}\right]}\end{array}$ & $\begin{array}{c}\mathrm{NH}_{3}-\mathrm{N}^{\mathrm{c}} \\
{\left[\mathrm{mg} \cdot \mathrm{kg}^{-1}\right]}\end{array}$ & $\begin{array}{c}\mathrm{NO}_{3}-\mathrm{N}^{\mathrm{d}} \\
{\left[\mathrm{mg} \cdot \mathrm{kg}^{-1}\right]}\end{array}$ & \begin{tabular}{|c|} 
Sand \\
{$[\%]$} \\
$(0.2-0.02)$ \\
\end{tabular} & $\begin{array}{c}\text { Silt } \\
{[\%]} \\
(\mathbf{0 . 0 2 - 0 . 0 0 2 )} \\
\end{array}$ & $\begin{array}{c}\text { Clay } \\
{[\%]} \\
(<\mathbf{0 . 0 0 2}) \\
\end{array}$ & \begin{tabular}{|c|} 
Bulk \\
density \\
{$\left[\mathrm{g} \cdot \mathrm{cm}^{-3}\right]$} \\
\end{tabular} & $\begin{array}{r}\text { Poro } \\
{[\%}\end{array}$ & $\begin{array}{l}C^{\mathrm{e}} \\
\left.\mathbf{h}^{-1}\right]\end{array}$ \\
\hline $0-15$ & $3 \pm 0.1$ & & & & & $21.1 \pm 3.7$ & $59.4 \pm 2.0$ & $19.5 \pm 2.1$ & 1.75 & & \\
\hline $5-30$ & $7.1 \pm 0.1$ & $0.6 \pm 0.1$ & $0.3 \pm 0.0$ & $1.6 \pm 0.0$ & $0.01 \pm 0.01$ & $15.8 \pm 1.5$ & $65.7 \pm 1.6$ & $18.5 \pm 0.9$ & 7 & & \\
\hline
\end{tabular}

${ }^{\mathrm{a}}$ o.m. - organic matter, ${ }^{\mathrm{b}} \mathrm{TN}$ - total nitrogen, ${ }^{\mathrm{c}} \mathrm{NH}_{3}-\mathrm{N}$ - ammonia nitrogen, ${ }^{\mathrm{d}} \mathrm{NO}_{3}-\mathrm{N}$ - nitrate nitrogen, ${ }^{\mathrm{e}} \mathrm{SHC}$ - saturated hydraulic conductivity 
Physical-chemical properties of the experimental plants

\begin{tabular}{|c|c|c|c|c|c|c|}
\hline $\begin{array}{c}\mathbf{V C}^{\mathbf{a}} \\
{[\%]}\end{array}$ & $\begin{array}{c}\text { Height } \\
{[\mathbf{c m}]}\end{array}$ & $\begin{array}{c}\text { Biomass } \\
{\left[\mathbf{k g} \cdot \mathbf{m}^{-\mathbf{2}}\right]}\end{array}$ & $\begin{array}{c}\text { FLWC }^{\mathbf{b}} \\
{[\%]}\end{array}$ & $\begin{array}{c}\mathbf{T N}^{\mathbf{c}} \\
{[\%]}\end{array}$ & $\begin{array}{c}\mathbf{T P}^{\mathbf{d}} \\
{[\%]}\end{array}$ & $\begin{array}{c}\mathbf{T K}^{\mathbf{e}} \\
{[\%]}\end{array}$ \\
\hline 100 & 50 & 0.679 & 46.98 & 0.56 & 0.08 & 0.57 \\
\hline
\end{tabular}

${ }^{\mathrm{a}} \mathrm{VC}$ - vegetation coverage, ${ }^{\mathrm{b}} \mathrm{FLWC}$ - fresh leaf water content, ${ }^{\mathrm{c}} \mathrm{TN}$ - total nitrogen, ${ }^{\mathrm{d}} \mathrm{TP}$ - total phosphorus, ${ }^{\mathrm{e}} \mathrm{TK}$ - total potassium

\section{Plot setup}

The experimental plot was established on a hill slope at $161 \mathrm{~m}$ above sea level. The experimental plot was $0.50 \mathrm{~m}$ wide and $15.00 \mathrm{~m}$ long and was covered with a flourishing Bermuda community. Wooden boards up to a depth of $30 \mathrm{~cm}$ were used on either side to hydrologically isolate the plots. These wooden boards were wedged into the soil until they reached the bedrock on each side of the plot. To prevent the subsurface water from running off, the soil on either side of the wooden boards was compacted.

\section{Discharge and runoff collection}

The primary experimental equipment included a large plastic tank $\left(6 \mathrm{~m}^{3}\right)$, a water pump, a cuboid tin overflow launder $(30 \mathrm{~cm} \times 40 \mathrm{~cm} \times 50 \mathrm{~cm})$ and a V-type trough (Fig. 2). The cuboid metal overflow launder was placed clinging to the topside of the plot. The V-type trough was installed at lower end of the plot to collect surface runoff. The simulated runoff was stored in the large plastic tank. During the experiment, the runoff water was pumped into the cuboid metal overflow launder at a steady flow rate, and the water flowed through the VFS and out from the V-type trough.

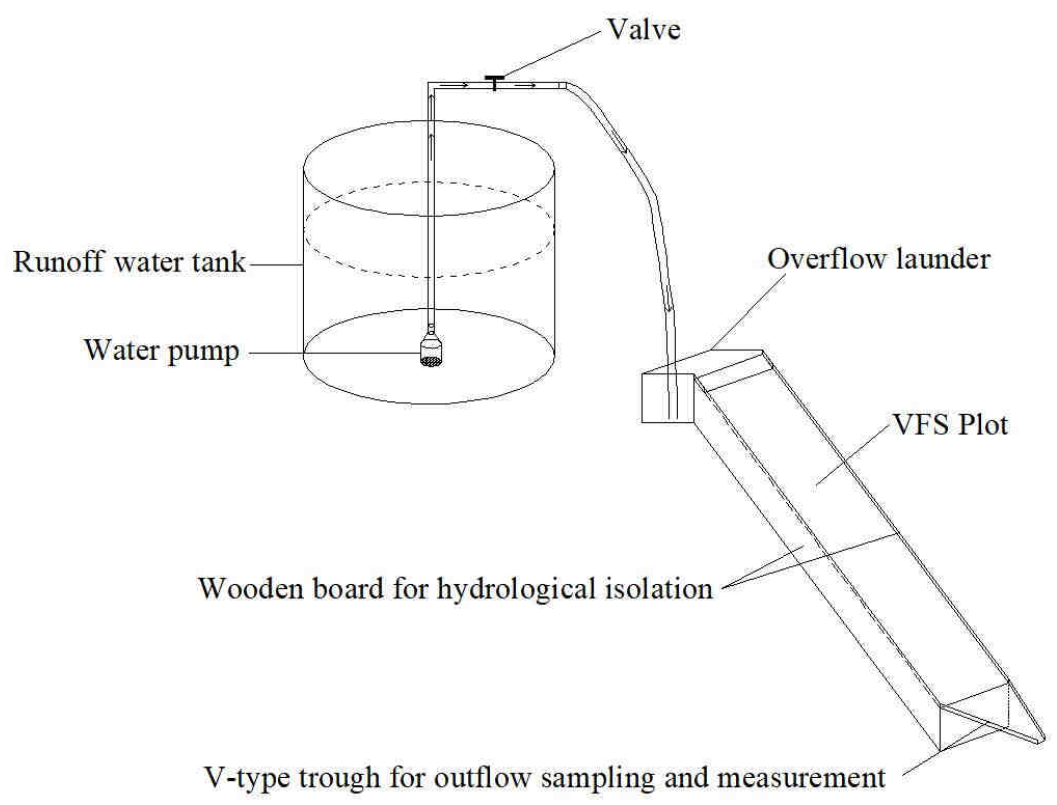

Fig. 2. Schematic diagram of plot and simulated runoff discharge equipment in experimental sites 


\section{Experimental design and analytical methods}

Danjiangkou Reservoir water was used for simulated runoff and the average $\mathrm{NH}_{4}-\mathrm{N}$, $\mathrm{NO}_{3}-\mathrm{N}$ and $\mathrm{TN}$ concentration were $0.13,0.75$ and $1.08 \mathrm{mg} / \mathrm{dm}^{3}$, respectively. Three concentrations of simulated runoff were prepared by adding specific proportions of $\mathrm{NH}_{4} \mathrm{Cl}$ and $\mathrm{KNO}_{3}$ to water, after subtracting the background concentrations of the water source. The three concentrations represented "normal to high" runoff events in the area and corresponded to three treatments of low (T1), moderate (T2) and high (T3). The inflow rate of the simulated runoff through the VFS was set at $0.2 \mathrm{dm}^{3} / \mathrm{s}$, which represented a local moderate intensity rainfall $(1.5 \mathrm{~mm} / \mathrm{min})$ in $10 \mathrm{~m}^{2}$ watershed with a runoff coefficient of 0.8. Each treatment was replicated three times, and nine trials were conducted in total. The trial interval of each treatment was 3 hours. For the first trial of each treatment, the VFS soil was pre-discharged with simulated runoff 3 hours before. The specific experimental design is shown in Table 3.

Table 3

Inflow parameters and the experimental scheme for simulated runoff discharge experiments

\begin{tabular}{|c|c|c|c|c|c|c|c|c|c|}
\hline \multirow{3}{*}{ Treatment } & \multirow{3}{*}{$\begin{array}{c}\text { Discharge } \\
\text { volume } \\
{\left[\mathrm{m}^{3}\right]}\end{array}$} & \multirow{2}{*}{\multicolumn{2}{|c|}{$\begin{array}{c}\text { Inflow rate } \\
{\left[\mathrm{dm}^{3} / \mathrm{s}\right]}\end{array}$}} & \multicolumn{6}{|c|}{ Inflow concentration $\left[\mathrm{mg} / \mathrm{dm}^{3}\right]$} \\
\hline & & & & \multicolumn{2}{|c|}{$\mathrm{NH}_{3}-\mathrm{N}$} & \multicolumn{2}{|c|}{$\mathrm{NO}_{3}-\mathrm{N}$} & \multicolumn{2}{|c|}{$\mathbf{T N}$} \\
\hline & & Design & Measured & Design & Measured & Design & Measured & Design & Measured \\
\hline T1 & 0.36 & 0.20 & 0.21 & 0.50 & 0.65 & 2.50 & 3.02 & 3.00 & 3.49 \\
\hline $\mathrm{T} 2$ & 0.36 & 0.20 & 0.20 & 1.00 & 1.15 & 4.00 & 4.54 & 5.00 & 5.06 \\
\hline T3 & 0.36 & 0.20 & 0.20 & 4.00 & 3.52 & 6.00 & 6.78 & 10.00 & 10.21 \\
\hline
\end{tabular}

$\mathrm{T} 1, \mathrm{~T} 2$ and $\mathrm{T} 3$ corresponded to three treatments of low, moderate and high

The duration of each trial was approximately $30 \mathrm{~min}$. After the trial began, inflow samples at initial, medium and late stages were collected and mixed as one sample. The surface flow was collected, and the flow rates were measured synchronously after outflow initiation. Sampling and measuring at the beginning of the experiment was frequent and was set to $1.5 \mathrm{~min}$. However, as the outflow rate stabilized, the sampling and measuring interval was increased to $3 \mathrm{~min}$.

Polyethylene bottles were used to store the water samples at $4{ }^{\circ} \mathrm{C}$. Within 24 hours of collection, these samples were analysed for $\mathrm{NH}_{3}-\mathrm{N}, \mathrm{NO}_{3}-\mathrm{N}$ and $\mathrm{TN}$ using standard methods. Indophenol blue colorimetry was used to test $\mathrm{NH}_{3}-\mathrm{N}$, cadmium amalgam and colorimetry was used to test $\mathrm{NO}_{3}-\mathrm{N}$ in acidified samples, and $\mathrm{TN}$ was tested by digestion with potassium sulphate and sulphuric acid digestion, followed by indophenol blue colorimetry. Three soil samples from the VFS plot were bulked together before each trial to analyse the soil moisture.

\section{Statistical analyses}

Nine trials were conducted under identical external conditions except for inflow concentrations. Repeated measures analysis of variance (ANOVA) and one-way ANOVA was used to compare the analysis of outflow rate, concentrations and loads among the three treatments, in addition to among the different times of each treatment.

The retention of the pollutants in the surface runoff by the VFS was achieved by both reducing runoff volume and pollutant concentration. Therefore, the runoff reduction rate $(R R R)$ was selected as the evaluation index for retention efficiency of runoff, and the concentration reduction rate $(C R R)$ and the load reduction rate $(L R R)$ were selected as the 
evaluation indexes for retention efficiency of $\mathrm{NH}_{3}-\mathrm{N}, \mathrm{NO}_{3}-\mathrm{N}$ and $\mathrm{TN}$. The evaluation equations were as follow:

$$
\begin{gathered}
R R R=\frac{V_{I}-V_{o}}{V_{I}} \cdot 100 \% \\
C R R=\frac{C_{I}-C_{o}}{C_{I}} \cdot 100 \% \\
L R R=\frac{C_{I} V_{I}-C_{o} V_{o}}{C_{I} V_{I}} \cdot 100 \%
\end{gathered}
$$

where $R R R$ is the runoff reduction rate [\%], CRR is the concentration reduction rate [\%], $L R R$ is the load reduction rate [\%], $C_{I}$ is the inflow concentration $\left[\mathrm{mg} / \mathrm{dm}^{3}\right], C_{O}$ is the outflow concentration $\left[\mathrm{mg} / \mathrm{dm}^{3}\right], V_{I}$ is the inflow volume $\left[\mathrm{dm}^{3}\right], V_{O}$ is the outflow volume $\left[\mathrm{dm}^{3}\right]$.

\section{Results}

\section{Retention efficiency of runoff}

Initial soil moisture content influences the process of runoff yield and then influences the retention efficiency of runoff. Usually, at low initial soil moisture content, more of the surface runoff is retained. The soil moisture in the VFS plot was artificially controlled by pre-discharging simulated runoff before each trial. The average initial soil moisture content was $37.0 \pm 3.9 \%$, which was not significantly different $(\mathrm{P}=0.35)$ among the nine trials. The average runoff yield time for each trial was $5.91 \pm 0.13$ minutes.

Hydrographs for outflow of the three treatments during trials are shown in Figure 3. The outflow rates in all treatments increased linearly with time. The results of analysis of variance indicated that the outflow rates at different times were highly significantly different among the three treatments $(\mathrm{F}=11.029, \mathrm{P}<0.001)$. Based on the results of pairwise comparisons, highly significant differences were detected between $\mathrm{T} 1$ and $\mathrm{T} 2$ $(\mathrm{P}=0.009)$ and $\mathrm{T} 1$ and $\mathrm{T} 3(\mathrm{P}<0.001)$, and a significant difference was detected between $\mathrm{T} 2$ and T3 $(\mathrm{P}=0.049)$. Normalizing the outflow rates of different inflow rates by outflow ratios, the results of analysis of variance indicated that the outflow ratios at different times were significantly different among the three treatments $(\mathrm{F}=8.440, \mathrm{P}=0.038)$. Based on the results of pairwise comparisons, highly significant differences were detected between $\mathrm{T} 1$ and $\mathrm{T} 3(\mathrm{P}<0.001)$, and a significant difference was detected between $\mathrm{T} 1$ and $\mathrm{T} 2$ $(\mathrm{P}=0.040)$, as well as between $\mathrm{T} 2$ and $\mathrm{T} 3(\mathrm{P}=0.045)$. These differences might be related to subtle differences among actual inflow rates and conditions of the VFS. The trials of the three treatments were conducted in stages, and therefore, the inflow rate had to be recalibrated before the first trial in each treatment because the equipment was reinstalled. Thus, the actual inflow rates were slightly different with a deviation rate of $5 \%$. The average inflow rates measured in T1, T2 and T3 were: $0.210,0.202$ and $0.195 \mathrm{dm}^{3} / \mathrm{s}$, respectively (see Table 3 ). 


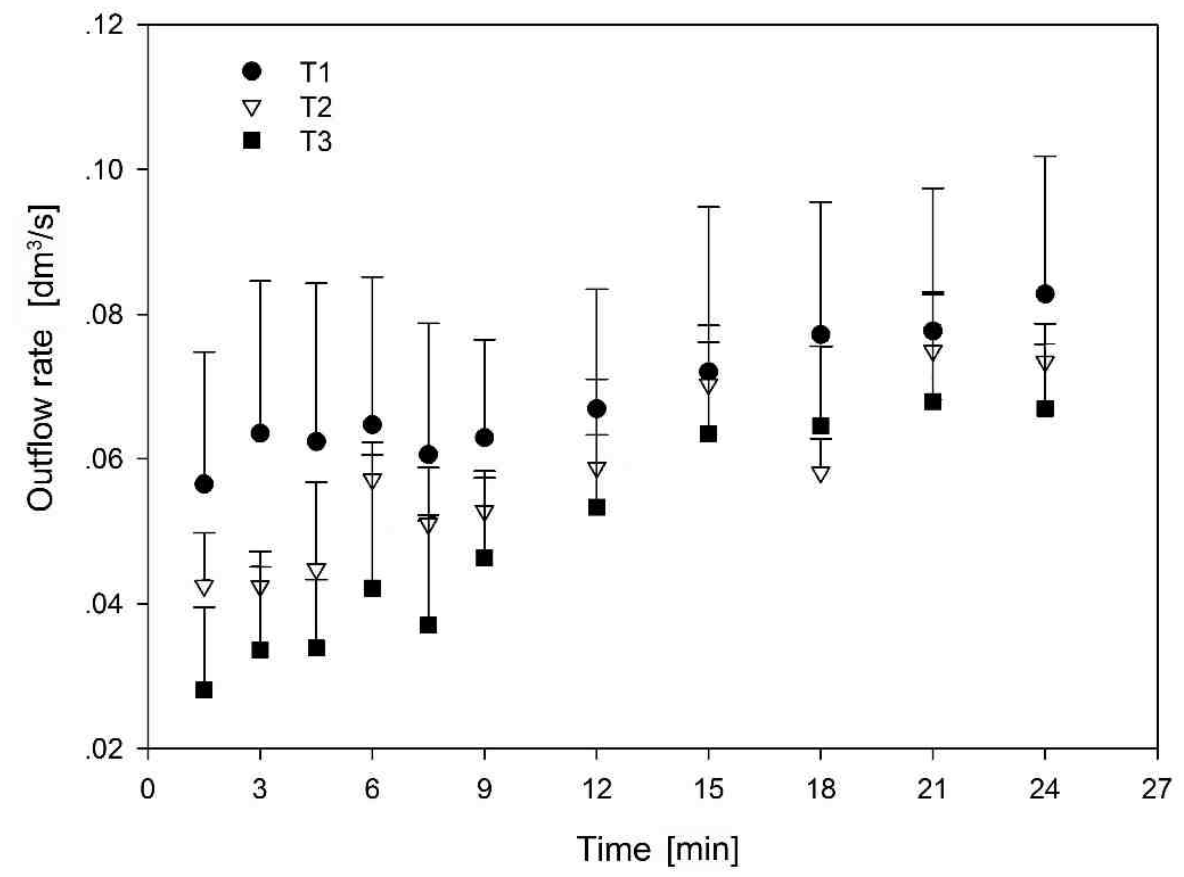

Fig. 3. Variation of outflow rate with time in T1, T2 and T3, corresponded to three treatments of low, moderate and high. The points represent the means $\pm S D$ (standard deviation) of three Replicates. The same applies to the tables that follow

Minutely outflow volumes and retention efficiencies at different times in the three treatments

\begin{tabular}{|c|c|c|c|c|c|c|}
\hline \multirow{2}{*}{$\begin{array}{c}\text { Time } \\
{[\mathbf{m i n}]}\end{array}$} & \multicolumn{2}{|c|}{ Minutely outflow volume $\left[\mathbf{d m}^{3}\right]$} & \multicolumn{2}{c|}{ Runoff reduction rate $(\boldsymbol{R R R})[\%]$} \\
\cline { 2 - 7 } & $\mathbf{T 1}$ & $\mathbf{T 2}$ & T3 & T1 & T2 & T3 \\
\hline 1.5 & $3.4 \pm 1.1 \mathrm{aA}$ & $2.55 \pm 0.44 \mathrm{aA}$ & $1.68 \pm 0.69 \mathrm{aA}$ & $73.1 \pm 8.7 \mathrm{aA}$ & $78.7 \pm 4.1 \mathrm{aA}$ & $86.1 \pm 5.7 \mathrm{aA}$ \\
\hline 3.0 & $3.8 \pm 1.3 \mathrm{aA}$ & $2.55 \pm 0.29 \mathrm{aA}$ & $2.02 \pm 0.69 \mathrm{aA}$ & $70 \pm 10 \mathrm{aA}$ & $79.0 \pm 2.4 \mathrm{aA}$ & $83.4 \pm 5.7 \mathrm{aA}$ \\
\hline 4.5 & $3.7 \pm 1.3 \mathrm{aA}$ & $2.69 \pm 0.72 \mathrm{aA}$ & $2.03 \pm 0.57 \mathrm{aA}$ & $70 \pm 10 \mathrm{aA}$ & $77.8 \pm 5.9 \mathrm{aA}$ & $83.2 \pm 4.7 \mathrm{aA}$ \\
\hline 6.0 & $3.9 \pm 1.2 \mathrm{aA}$ & $3.43 \pm 0.21 \mathrm{aA}$ & $2.5 \pm 1.2 \mathrm{aA}$ & $69.2 \pm 9.8 \mathrm{aA}$ & $71.7 \pm 1.7 \mathrm{aA}$ & $79 \pm 10 \mathrm{aA}$ \\
\hline 7.5 & $3.6 \pm 1.1 \mathrm{aA}$ & $3.06 \pm 0.47 \mathrm{aA}$ & $2.22 \pm 0.92 \mathrm{aA}$ & $71.1 \pm 8.7 \mathrm{aA}$ & $74.4 \pm 3.8 \mathrm{aA}$ & $81.7 \pm 7.6 \mathrm{aA}$ \\
\hline 9.0 & $3.78 \pm 0.82 \mathrm{aA}$ & $3.17 \pm 0.27 \mathrm{aA}$ & $2.78 \pm 0.72 \mathrm{aA}$ & $70.0 \pm 6.5 \mathrm{aA}$ & $73.9 \pm 2.3 \mathrm{aA}$ & $77.0 \pm 5.9 \mathrm{aA}$ \\
\hline 12.0 & $4.02 \pm 0.99 \mathrm{aA}$ & $3.53 \pm 0.27 \mathrm{aA}$ & $3.2 \pm 1.1 \mathrm{aA}$ & $68.1 \pm 7.9 \mathrm{aA}$ & $70.9 \pm 2.2 \mathrm{aA}$ & $73.6 \pm 8.7 \mathrm{aA}$ \\
\hline 15.0 & $4.3 \pm 1.4 \mathrm{aA}$ & $4.22 \pm 0.35 \mathrm{aA}$ & $3.81 \pm 0.90 \mathrm{aA}$ & $66 \pm 11 \mathrm{aA}$ & $65.2 \pm 2.9 \mathrm{aA}$ & $68.6 \pm 7.4 \mathrm{aA}$ \\
\hline 18.0 & $4.6 \pm 1.1 \mathrm{aA}$ & $3.49 \pm 0.28 \mathrm{aA}$ & $3.87 \pm 0.66 \mathrm{aA}$ & $63.2 \pm 8.7 \mathrm{aA}$ & $71.2 \pm 2.3 \mathrm{aA}$ & $68.0 \pm 5.5 \mathrm{aA}$ \\
\hline 21.0 & $4.7 \pm 1.2 \mathrm{aA}$ & $4.50 \pm 0.49 \mathrm{aA}$ & $4.08 \pm 0.89 \mathrm{aA}$ & $63.0 \pm 9.4 \mathrm{aA}$ & $62.9 \pm 4.0 \mathrm{aA}$ & $66.4 \pm 7.3 \mathrm{aA}$ \\
\hline 24.0 & $5.0 \pm 1.1 \mathrm{aA}$ & $4.41 \pm 0.31 \mathrm{aA}$ & $4.02 \pm 0.53 \mathrm{aA}$ & $60.6 \pm 9.1 \mathrm{aA}$ & $63.6 \pm 2.6 \mathrm{aA}$ & $66.8 \pm 4.4 \mathrm{aA}$ \\
\hline
\end{tabular}

Different lowercase letters and capital letters in the same row indicate significant differences among different treatments at 5 and $1 \%$ levels of probability, respectively. The same applies to the tables that follow

The subsurface flow rates at different times, which were obtained by subtracting outflow rates from inflow rates, were analysed using repeated measures analysis of variance, and no significant differences were detected in subsurface flow rates among the 
three treatments $(\mathrm{F}=0.477, \mathrm{P}=0.625)$. Therefore, the three treatments had no significant influence on the retention efficiency of runoff, and the differences among outflow rates were caused by actual inflow rates. Any differences in the VFS caused by plant growth among the three treatments were not significant during the experiments.

The minutely outflow volumes and $R R R s$ at different times in the three treatments are listed in Table 4. The outflow volumes increased with time in all treatments. T-test comparative analyses at same time shown that there was no difference in the outflow volumes among three treatments. By contrast, in all three treatments, the RRRs with time decreased. The RRRs in T1, T2 and T3 were initially 73.1, 78.7 and $86.1 \%$, respectively, and ultimately decreased to $60.6,63.6$ and $66.8 \%$, respectively. The differences of $R R R s$ at the same runoff yield time among three treatments decreased gradually with time.

\section{Retention efficiency of $\mathrm{NH}_{3}-\mathrm{N}$}

Concentration-time graphs of the three treatments for $\mathrm{NH}_{3}-\mathrm{N}$ during trials are shown in Figure 4. The $\mathrm{NH}_{3}-\mathrm{N}$ concentrations increased in all three treatments with time and displayed excellent significant linear correlations. The concentrations of $\mathrm{NH}_{3}-\mathrm{N}$ in $\mathrm{T} 1, \mathrm{~T} 2$ and T3 increased at rates of $0.0046,0.0071$ and $0.0559 \mathrm{mg} / \mathrm{dm}^{3} \cdot \mathrm{min}$, respectively. The increase in rate in T3 was higher than that in T1 and T2. The results of the analysis of variance indicated that the $\mathrm{NH}_{3}-\mathrm{N}$ concentrations at different times were highly significantly different among the three treatments $(\mathrm{F}=170.549, \mathrm{P}<0.001)$.

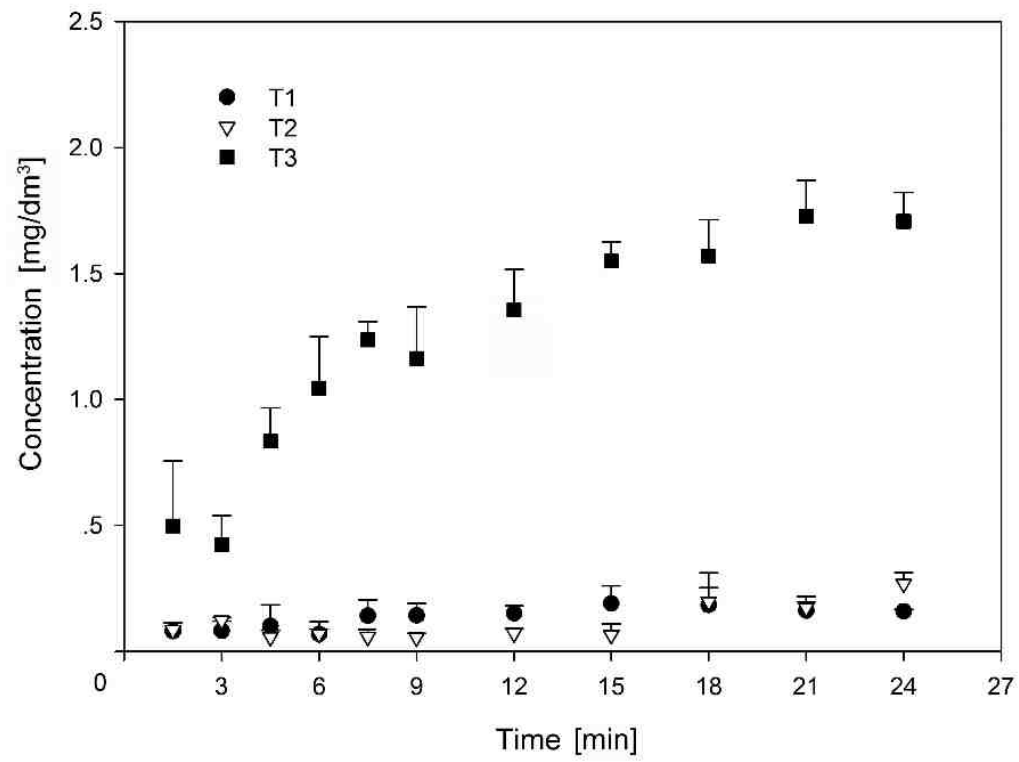

Fig. 4. Variation of $\mathrm{NH}_{3}-\mathrm{N}$ concentration with time in $\mathrm{T} 1, \mathrm{~T} 2$ and $\mathrm{T} 3$

The results of pairwise comparisons revealed that the differences were primarily reflected in that between $\mathrm{T} 1$ and $\mathrm{T} 3(\mathrm{P}<0.001)$ and between $\mathrm{T} 2$ and $\mathrm{T} 3(\mathrm{P}<0.001)$, with no significant difference detected between $\mathrm{T} 1$ and $\mathrm{T} 2(\mathrm{P}=0.749)$. The results of repeated measures ANOVA indicated that the $\mathrm{NH}_{3}-\mathrm{N}$ concentrations in the three treatments 
were highly significantly different at different times $(\mathrm{F}=24.428, \mathrm{P}<0.001)$. The differences were not significant in $\mathrm{T} 1(\mathrm{~F}=1.431, \mathrm{P}=0.230)$ but were highly significant in $\mathrm{T} 2(\mathrm{~F}=14.881, \mathrm{P}<0.001)$ and $\mathrm{T} 3(\mathrm{~F}=25.070, \mathrm{P}<0.001)$. Based on the above analysis, The $\mathrm{NH}_{3}-\mathrm{N}$ outflow concentrations increased very slowly with time in both $\mathrm{T} 1$ and $\mathrm{T} 2$, but rapidly in $\mathrm{T} 3$. The average $\mathrm{NH}_{3}-\mathrm{N}$ outflow concentration in $\mathrm{T} 3$ was much higher than in $\mathrm{T} 1$ and $\mathrm{T} 2$.

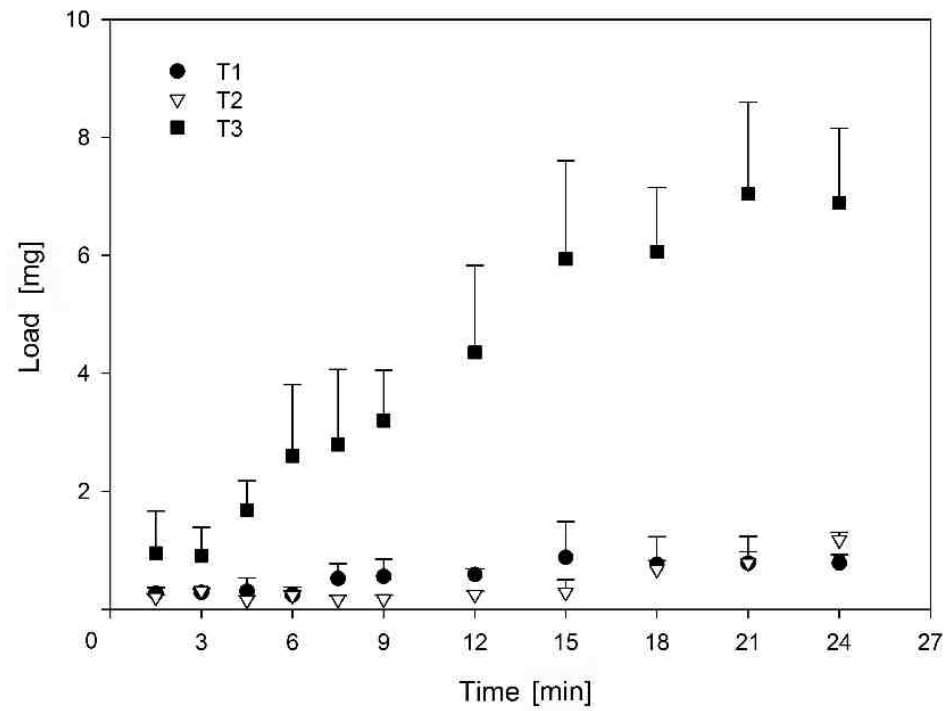

Fig. 5. Variation of $\mathrm{NH}_{3}-\mathrm{N}$ load with time in $\mathrm{T} 1, \mathrm{~T} 2$ and $\mathrm{T} 3$

Retention efficiencies of $\mathrm{NH}_{3}-\mathrm{N}$ at different times in the three treatments

\begin{tabular}{|c|c|c|c|c|c|c|}
\hline \multirow{2}{*}{$\begin{array}{c}\text { Time } \\
{[\mathbf{m i n}]}\end{array}$} & \multicolumn{2}{|c|}{ Concentration reduction rate $(\boldsymbol{C R R})[\%]$} & \multicolumn{2}{c|}{ Load reduction rate $(\boldsymbol{L R R})[\%]$} \\
\cline { 2 - 7 } & $\mathbf{T 1}$ & $\mathbf{T 2}$ & $\mathbf{T 3}$ & T1 & T2 & T3 \\
\hline 1.5 & $87.7 \pm 1.5 \mathrm{bA}$ & $92.7 \pm 2.5 \mathrm{aA}$ & $85.9 \pm 7.3 \mathrm{abA}$ & $96.8 \pm 1.1 \mathrm{aA}$ & $98.4 \pm 0.3 \mathrm{aA}$ & $97.5 \pm 1.9 \mathrm{aA}$ \\
\hline 3.0 & $87.4 \pm 5.7 \mathrm{aA}$ & $89.4 \pm 1.1 \mathrm{aA}$ & $87.9 \pm 3.2 \mathrm{aA}$ & $96.7 \pm 0.7 \mathrm{aA}$ & $97.6 \pm 0.4 \mathrm{aA}$ & $97.6 \pm 1.3 \mathrm{aA}$ \\
\hline 4.5 & $84 \pm 13 \mathrm{abB}$ & $95.1 \pm 2.3 \mathrm{bB}$ & $76.3 \pm 3.8 \mathrm{aA}$ & $96.4 \pm 2.6 \mathrm{abA}$ & $98.8 \pm 0.6 \mathrm{bA}$ & $95.6 \pm 1.3 \mathrm{aA}$ \\
\hline 6.0 & $89.4 \pm 7.5 \mathrm{bAB}$ & $94.0 \pm 1.7 \mathrm{bB}$ & $70.3 \pm 5.9 \mathrm{aA}$ & $97.1 \pm 1.5 \mathrm{aA}$ & $98.2 \pm 0.6 \mathrm{aA}$ & $93.2 \pm 3.1 \mathrm{aA}$ \\
\hline 7.5 & $78.1 \pm 9.6 \mathrm{aAB}$ & $95.0 \pm 2.7 \mathrm{bB}$ & $64.9 \pm 2.1 \mathrm{aA}$ & $93.9 \pm 3.0 \mathrm{aA}$ & $98.7 \pm 0.5 \mathrm{bA}$ & $92.7 \pm 3.3 \mathrm{aA}$ \\
\hline 9.0 & $78.0 \pm 7.3 \mathrm{aAB}$ & $95.2 \pm 1.5 \mathrm{bB}$ & $67.0 \pm 5.8 \mathrm{aA}$ & $93.5 \pm 3.4 \mathrm{abAB}$ & $98.6 \pm 0.5 \mathrm{bB}$ & $91.7 \pm 2.2 \mathrm{aA}$ \\
\hline 12.0 & $76.9 \pm 4.8 \mathrm{cA}$ & $93.8 \pm 1.7 \mathrm{bB}$ & $61.5 \pm 4.6 \mathrm{aA}$ & $93.1 \pm 1.1 \mathrm{aB}$ & $98.1 \pm 0.5 \mathrm{bA}$ & $88.7 \pm 3.9 \mathrm{aAB}$ \\
\hline 15.0 & $71 \pm 11 \mathrm{aAB}$ & $94.3 \pm 3.9 \mathrm{bB}$ & $56.0 \pm 2.2 \mathrm{aA}$ & $89.7 \pm 7.1 \mathrm{abAB}$ & $97.8 \pm 1.7 \mathrm{bB}$ & $84.6 \pm 4.3 \mathrm{aA}$ \\
\hline 18.0 & $72 \pm 20 \mathrm{abA}$ & $82.9 \pm 4.9 \mathrm{bB}$ & $55.4 \pm 4.1 \mathrm{aA}$ & $91.1 \pm 5.5 \mathrm{abAB}$ & $94.8 \pm 1.1 \mathrm{bB}$ & $84.2 \pm 2.8 \mathrm{aA}$ \\
\hline 21.0 & $75.1 \pm 8.6 \mathrm{bAB}$ & $84.9 \pm 2.1 \mathrm{bB}$ & $50.9 \pm 4.0 \mathrm{aA}$ & $90.9 \pm 5.3 \mathrm{abAB}$ & $94.0 \pm 1.5 \mathrm{bB}$ & $81.7 \pm 4.0 \mathrm{aA}$ \\
\hline 24.0 & $75.5 \pm 1.2 \mathrm{bB}$ & $76.6 \pm 3.9 \mathrm{bB}$ & $51.5 \pm 3.3 \mathrm{aA}$ & $90.9 \pm 1.6 \mathrm{bB}$ & $91.0 \pm 1.0 \mathrm{bB}$ & $82.1 \pm 3.3 \mathrm{aA}$ \\
\hline
\end{tabular}

The minutely $\mathrm{NH}_{3}-\mathrm{N}$ loads at different times were shown in Figure 5. The $\mathrm{NH}_{3}-\mathrm{N}$ load remained unchanged firstly and increased later with the increase of inflow concentration. The $\mathrm{NH}_{3}-\mathrm{N}$ load increased in all three treatments with time and displayed significant linear correlations. The results of the analysis of variance detected significant differences in the $\mathrm{NH}_{3}-\mathrm{N}$ load among the three treatments $(\mathrm{F}=60.769, \mathrm{P}<0.001)$ and among different times 
$(\mathrm{F}=257.00, \mathrm{P}<0.001)$. The results of pairwise comparisons indicated that the differences among the three treatments were primarily a reflection of that between $\mathrm{T} 1$ and $\mathrm{T} 3$ $(\mathrm{P}<0.001)$ and between $\mathrm{T} 2$ and T3 $(\mathrm{P}<0.001)$. No significant difference was found between $\mathrm{T} 1$ and $\mathrm{T} 2(\mathrm{P}=0.688)$.

The CRRs and LRRs of $\mathrm{NH}_{3}-\mathrm{N}$ at different times in the three treatments are shown in Table 5. The CRRs in $\mathrm{T} 2$ were higher than those in $\mathrm{T} 1$ and $\mathrm{T} 3$. The CRRs in T1 slightly decreased with time and then fluctuated from 70.7 to $87.7 \%$. The $C R R s$ in T2 remained almost unchanged in the early and middle stages at an average of $93.7 \%$ and then decreased to $76.6 \%$ at the end. The CRRs in T3 decreased from 85.9 to $51.5 \%$ with time. The LRRs of $\mathrm{NH}_{3}-\mathrm{N}$ in $\mathrm{T} 1$ and $\mathrm{T} 2$ decreased very slowly with time. The LRRs in $\mathrm{T} 3$ were lower than those in $\mathrm{T} 1$ and $\mathrm{T} 2$ and decreased more rapidly with time.

\section{Retention efficiency of $\mathrm{NO}_{3}-\mathrm{N}$}

Concentration-time graphs of the three treatments for $\mathrm{NO}_{3}-\mathrm{N}$ during trials are shown in Figure 6. The $\mathrm{NO}_{3}-\mathrm{N}$ concentrations in $\mathrm{T} 1, \mathrm{~T} 2$ and $\mathrm{T} 3$ all remained unchanged with time, fluctuating from 2.44 to $2.95,3.99$ to 4.27 and 5.21 to $6.40 \mathrm{mg} / \mathrm{dm}^{3}$, respectively. The results of the analysis variance indicated that the $\mathrm{NO}_{3}-\mathrm{N}$ concentrations at different times were highly significantly different among the three treatments $(F=454.99$, $\mathrm{P}<0.001)$.

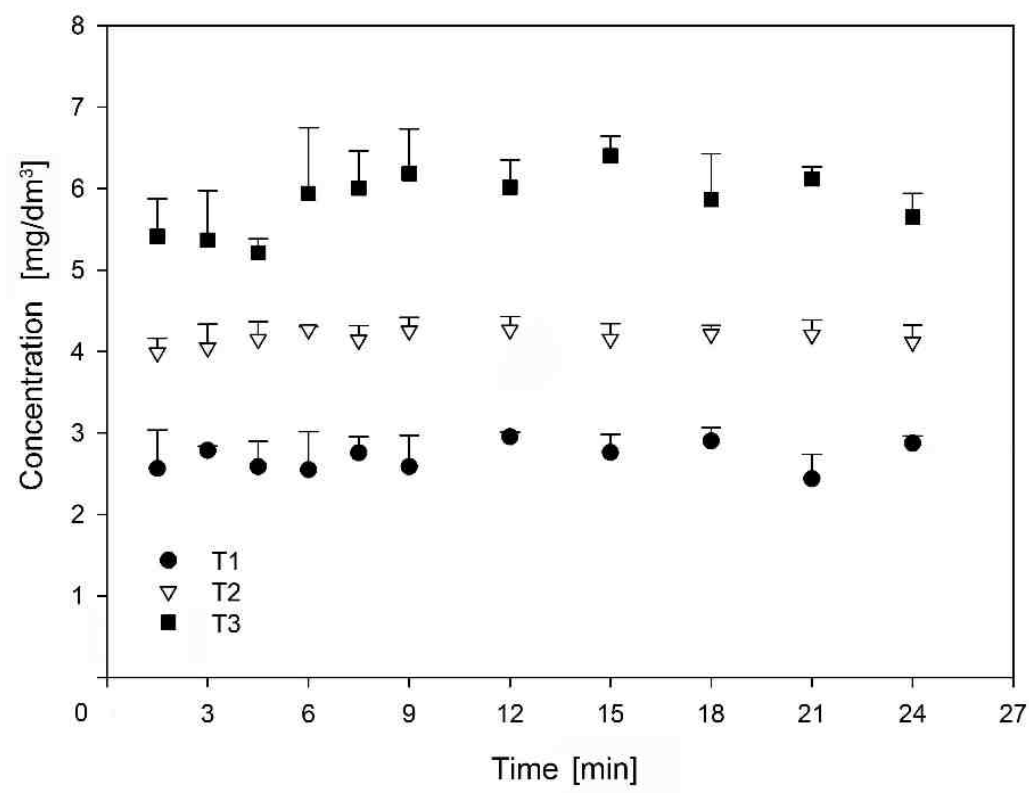

Fig. 6. Variation of $\mathrm{NO}_{3}-\mathrm{N}$ concentration with time in $\mathrm{T} 1, \mathrm{~T} 2$ and $\mathrm{T} 3$

The results of pairwise comparisons also indicated that the differences between each of the treatments were highly significant (all were $\mathrm{P}<0.001$ ). The results of the repeated measures ANOVA demonstrated that the $\mathrm{NO}_{3}-\mathrm{N}$ concentrations in the three treatments were significantly different among the different times $(\mathrm{F}=2.041, \mathrm{P}=0.042)$. However, the 
$\mathrm{NO}_{3}-\mathrm{N}$ concentrations were not significantly different among different times in $\mathrm{T} 1$ $(\mathrm{F}=1.033, \mathrm{P}=0.44), \mathrm{T} 2(\mathrm{~F}=0.727, \mathrm{P}=0.69)$ and $\mathrm{T} 3(\mathrm{~F}=1.975, \mathrm{P}=0.088)$. Based on the above analysis, the $\mathrm{NO}_{3}-\mathrm{N}$ concentrations increased significantly with the increase of inflow concentration but did not increase significantly with time.

Although the $\mathrm{NO}_{3}-\mathrm{N}$ concentrations in the three treatments increased slightly with time, the minutely $\mathrm{NO}_{3}-\mathrm{N}$ loads increased more rapidly with time (Fig. 7). Based on the analysis of variance, the $\mathrm{NO}_{3}-\mathrm{N}$ loads were highly significantly different among the three treatments $(\mathrm{F}=15.16, \mathrm{P}<0.001)$ and among the different times $(\mathrm{F}=9.16, \mathrm{P}<0.001)$. The results of pairwise comparisons among the three treatments showed that the $\mathrm{NO}_{3}-\mathrm{N}$ loads at different times were all highly significantly different between $\mathrm{T} 1$ and $\mathrm{T} 2$ $(\mathrm{P}=0.007)$, $\mathrm{T} 2$ and $\mathrm{T} 3(\mathrm{P}=0.007)$ and $\mathrm{T} 1$ and $\mathrm{T} 3(\mathrm{P}<0.001)$. As the above analysis shows, the three treatments had highly significant effects on the $\mathrm{NO}_{3}-\mathrm{N}$ load out of the VFS.

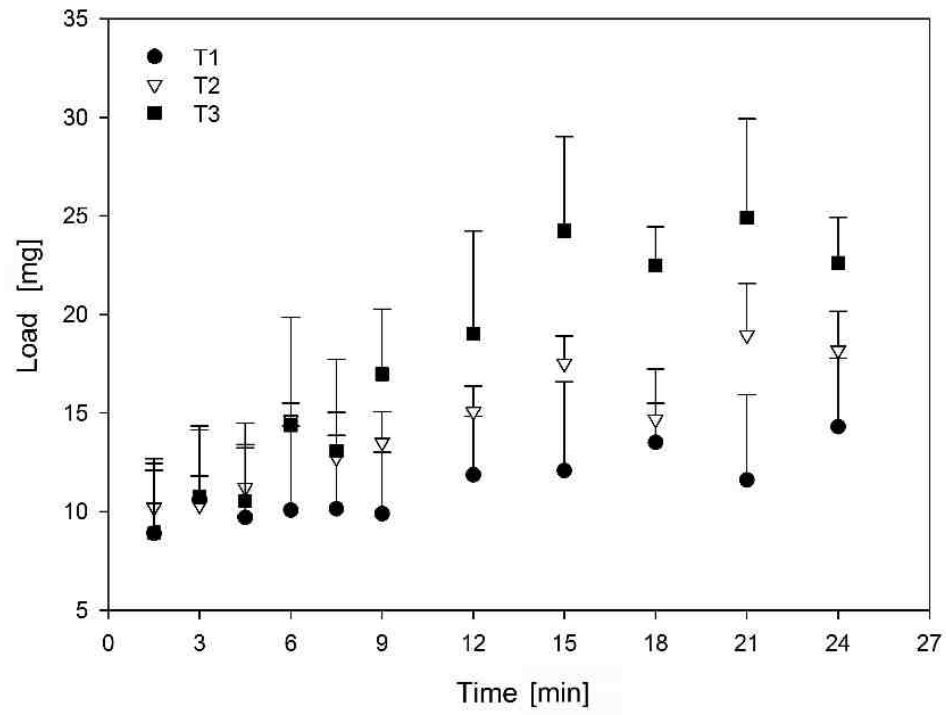

Fig. 7. Variation of $\mathrm{NO}_{3}-\mathrm{N}$ load with time in $\mathrm{T} 1, \mathrm{~T} 2$ and $\mathrm{T} 3$

Retention efficiencies of $\mathrm{NO}_{3}-\mathrm{N}$ at different times in the three treatments

Table 6

\begin{tabular}{|c|c|c|c|c|c|c|}
\hline \multirow{2}{*}{$\begin{array}{c}\text { Time } \\
{[\mathbf{m i n}]}\end{array}$} & \multicolumn{2}{|c|}{ Concentration reduction rate $(\boldsymbol{C R R})[\%]$} & \multicolumn{3}{c|}{ Load reduction rate $(\boldsymbol{L R R})[\%]$} \\
\cline { 2 - 7 } & $\mathbf{T 1}$ & $\mathbf{T 2}$ & $\mathbf{T 3}$ & $\mathbf{T 1}$ & $\mathbf{T 2}$ & T3 \\
\hline 1.5 & $15 \pm 16 \mathrm{aA}$ & $10.8 \pm 4.0 \mathrm{aA}$ & $20.2 \pm 6.8 \mathrm{aA}$ & $77.7 \pm 9.5 \mathrm{aA}$ & $80.0 \pm 4.4 \mathrm{aA}$ & $88.0 \pm 4.3 \mathrm{aA}$ \\
\hline 3.0 & $7.8 \pm 1.7 \mathrm{aA}$ & $9.5 \pm 6.5 \mathrm{aA}$ & $20.9 \pm 9.0 \mathrm{aA}$ & $73.4 \pm 8.8 \mathrm{aA}$ & $79.8 \pm 2.9 \mathrm{aA}$ & $85.5 \pm 4.9 \mathrm{aA}$ \\
\hline 4.5 & $14 \pm 10 \mathrm{abA}$ & $7.1 \pm 4.8 \mathrm{bB}$ & $23.1 \pm 2.5 \mathrm{aA}$ & $75.7 \pm 9.3 \mathrm{aA}$ & $78.0 \pm 6.4 \mathrm{aA}$ & $85.8 \pm 3.7 \mathrm{aA}$ \\
\hline 6.0 & $16 \pm 15 \mathrm{aA}$ & $4.5 \pm 0.8 \mathrm{aA}$ & $12 \pm 12 \mathrm{aA}$ & $75 \pm 11 \mathrm{aA}$ & $71.3 \pm 1.7 \mathrm{aA}$ & $80.6 \pm 7.4 \mathrm{aA}$ \\
\hline 7.5 & $8.8 \pm 6.6 \mathrm{aA}$ & $7.3 \pm 3.9 \mathrm{aA}$ & $11.4 \pm 6.8 \mathrm{aA}$ & $74.6 \pm 9.4 \mathrm{aA}$ & $75.0 \pm 4.5 \mathrm{aA}$ & $82.3 \pm 6.3 \mathrm{aA}$ \\
\hline 9.0 & $14 \pm 13 \mathrm{aA}$ & $4.8 \pm 3.7 \mathrm{aA}$ & $8.8 \pm 8.1 \mathrm{aA}$ & $75.2 \pm 7.8 \mathrm{aA}$ & $73.5 \pm 3.1 \mathrm{aA}$ & $77.1 \pm 4.5 \mathrm{aA}$ \\
\hline 12.0 & $2.2 \pm 1.9 \mathrm{bA}$ & $4.6 \pm 3.7 \mathrm{abA}$ & $11.3 \pm 5.0 \mathrm{aA}$ & $70.2 \pm 7.5 \mathrm{aA}$ & $70.5 \pm 2.5 \mathrm{aA}$ & $74.3 \pm 7.0 \mathrm{aA}$ \\
\hline 15.0 & $8.6 \pm 7.4 \mathrm{aA}$ & $7.1 \pm 4.2 \mathrm{aA}$ & $5.6 \pm 3.6 \mathrm{aA}$ & $70 \pm 11 \mathrm{aA}$ & $65.6 \pm 2.7 \mathrm{aA}$ & $67.3 \pm 6.5 \mathrm{aA}$ \\
\hline 18.0 & $4.0 \pm 5.5 \mathrm{aA}$ & $5.7 \pm 2.4 \mathrm{aA}$ & $13.5 \pm 8.2 \mathrm{aA}$ & $66.1 \pm 9.3 \mathrm{aA}$ & $71.2 \pm 1.6 \mathrm{aA}$ & $69.6 \pm 2.7 \mathrm{aA}$ \\
\hline 21.0 & $19.3 \pm 9.9 \mathrm{aA}$ & $5.9 \pm 4.2 \mathrm{aA}$ & $9.7 \pm 2.2 \mathrm{aA}$ & $71 \pm 11 \mathrm{aA}$ & $62.8 \pm 5.2 \mathrm{aA}$ & $66.4 \pm 6.8 \mathrm{aA}$ \\
\hline 24.0 & $4.8 \pm 2.9 \mathrm{bA}$ & $7.9 \pm 4.7 \mathrm{abA}$ & $16.7 \pm 4.3 \mathrm{aA}$ & $64.1 \pm 8.7 \mathrm{aA}$ & $64.3 \pm 3.9 \mathrm{aA}$ & $69.4 \pm 3.1 \mathrm{aA}$ \\
\hline
\end{tabular}


The CRRs in T1, T2 and T3 were relatively low and averaged 10.5, 6.8 and $14.0 \%$, respectively, fluctuating and decreasing with time (Table 6). The LRRs of $\mathrm{NO}_{3}-\mathrm{N}$ in T1, T2 and T3 averaged 72.0, 72.0 and $76.9 \%$ and decreased with time.

\section{Retention efficiency of TN}

Concentration-time graphs for $\mathrm{TN}$ of the three treatments during trials are shown in Figure 8. The TN concentrations in $\mathrm{T} 1, \mathrm{~T} 2$ and $\mathrm{T} 3$ all remained unchanged with time, respectively. Based on the analysis of variance, the $\mathrm{TN}$ concentrations at different times were highly significantly different among the three treatments $(\mathrm{F}=39.224, \mathrm{P}<0.001)$. The results of pairwise comparisons also showed highly significant differences between $\mathrm{T} 1$ and T2 $(\mathrm{P}=0.016)$, between T2 and T3 $(\mathrm{P}<0.001)$ and between T1 and T3 $(\mathrm{P}<0.001)$. According to the repeated measures ANOVA, the TN concentrations in the three treatments were not significantly different among the different times $(\mathrm{F}=0.711, \mathrm{P}=0.710)$. Based on the above analysis, the three treatments had highly significant effects on the average TN concentration of each trial but did not significantly influence the changes in $\mathrm{TN}$ concentrations with time.

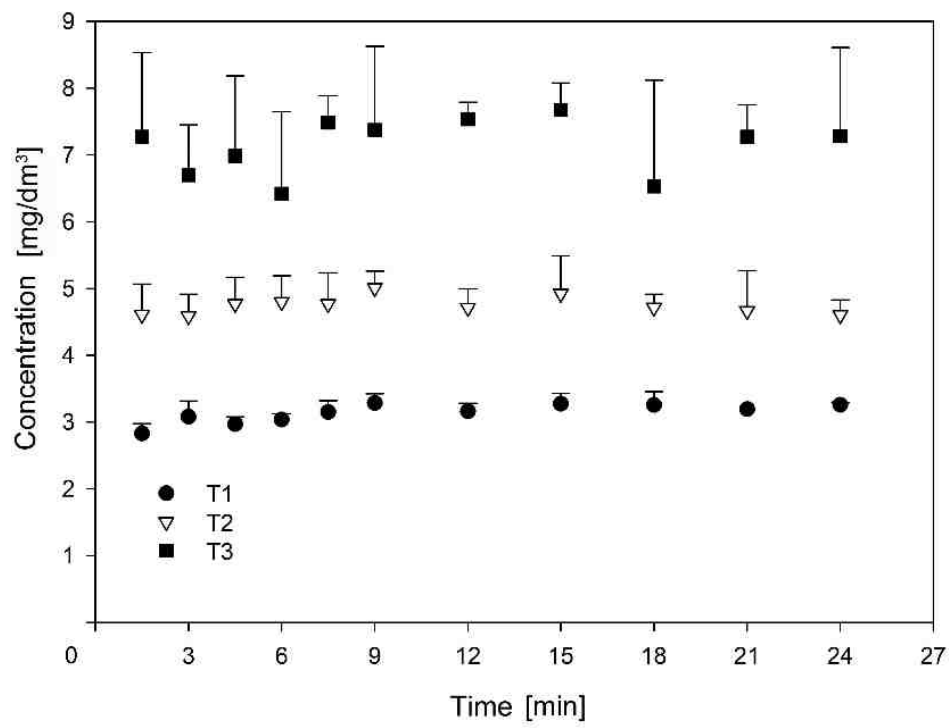

Fig. 8. Variation of $\mathrm{TN}$ concentrations with time in $\mathrm{T} 1, \mathrm{~T} 2$ and $\mathrm{T} 3$

The TN loads in the three treatments all had significant positive linear correlations with time (Fig. 9). The results of the analysis of variance showed that the minutely TN loads at different times were highly significantly different among the three treatments $(\mathrm{F}=15.925, \mathrm{P}<0.001)$. The results of pairwise comparisons also showed remarkable differences between $\mathrm{T} 1$ and $\mathrm{T} 2(\mathrm{P}=0.02)$, and highly significant differences between $\mathrm{T} 2$ and T3 $(\mathrm{P}=0.002)$ and between $\mathrm{T} 1$ and $\mathrm{T} 3(\mathrm{P}<0.001)$. Based on the repeated measures ANOVA, the TN loads were also highly significantly different among different times $(\mathrm{F}=6.301, \mathrm{P}<0.001)$. The results of pairwise comparisons showed that the differences among different times were not significant in $\mathrm{T} 1(\mathrm{~F}=0.872, \mathrm{P}=0.571)$ but were highly 
significant in $\mathrm{T} 2(\mathrm{~F}=3.983, \mathrm{P}=0.003)$ and significant in $\mathrm{T} 3(\mathrm{~F}=3.089, \mathrm{P}=0.013)$. As the above analysis shows, the three treatments had a significant influence on the TN load, which increased with both inflow concentrations and time.

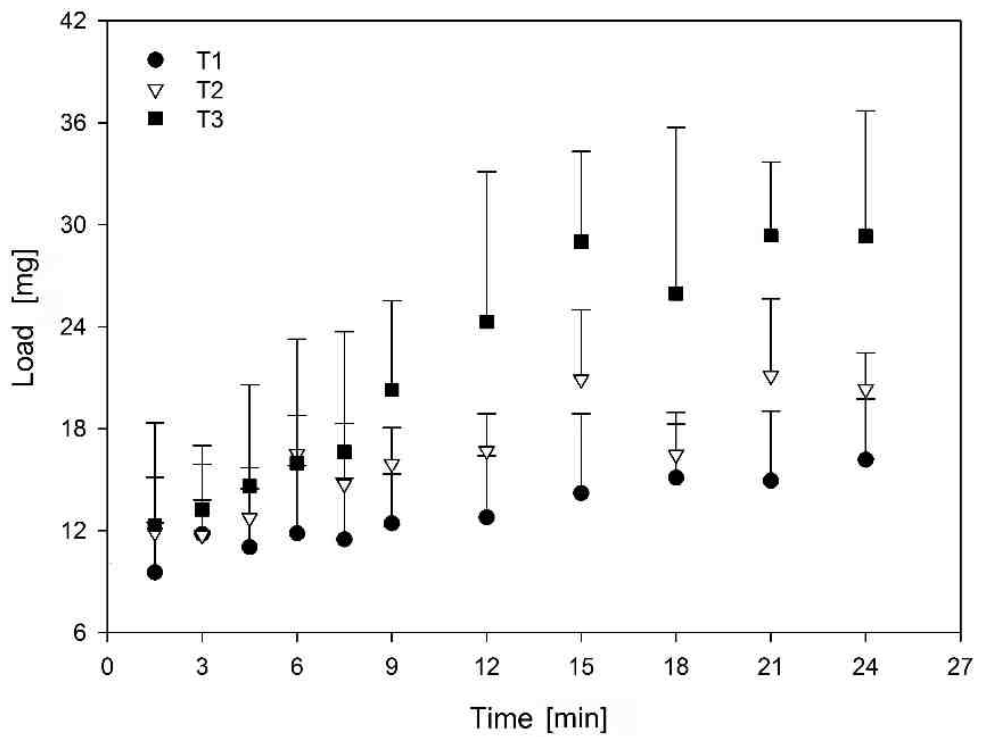

Fig. 9. Variation of TN loads with time in $\mathrm{T} 1, \mathrm{~T} 2$ and $\mathrm{T} 3$

Retention efficiencies of $\mathrm{TN}$ at different times in the three treatments

\begin{tabular}{|c|c|c|c|c|c|c|}
\hline \multirow{2}{*}{$\begin{array}{c}\text { Time } \\
{[\mathbf{m i n}]}\end{array}$} & \multicolumn{2}{|c|}{ Concentration reduction rate $(\boldsymbol{C R R})[\%]$} & \multicolumn{2}{c|}{ Load reduction rate $(\boldsymbol{L R R})[\%]$} \\
\hline 1.5 & $\mathbf{T 1}$ & $\mathbf{T 2}$ & $\mathbf{T 3}$ & T1 & T2 & T3 \\
\hline 3.0 & $11.9 \pm 4.1 \mathrm{aA}$ & $17.0 \pm 8.3 \mathrm{aA}$ & $29 \pm 12 \mathrm{aA}$ & $79.3 \pm 6.3 \mathrm{aA}$ & $81.2 \pm 5.2 \mathrm{aA}$ & $89.0 \pm 5.4 \mathrm{aA}$ \\
\hline 4.5 & $14.9 \pm 3.1 \mathrm{aA}$ & $17.3 \pm 5.9 \mathrm{bA}$ & $34.4 \pm 7.4 \mathrm{aA}$ & $74.4 \pm 8.9 \mathrm{aA}$ & $81.5 \pm 3.3 \mathrm{aA}$ & $88.1 \pm 3.4 \mathrm{aA}$ \\
\hline 6.0 & $13.0 \pm 2.5 \mathrm{bA}$ & $13.5 \pm 7.0 \mathrm{bA}$ & $37 \pm 12 \mathrm{aA}$ & $74.3 \pm 8.7 \mathrm{aA}$ & $73.9 \pm 3.6 \mathrm{aA}$ & $85.7 \pm 6.6 \mathrm{aA}$ \\
\hline 7.5 & $9.8 \pm 4.9 \mathrm{bB}$ & $14.1 \pm 8.4 \mathrm{abAB}$ & $26.7 \pm 3.9 \mathrm{aA}$ & $75.1 \pm 7.8 \mathrm{aA}$ & $76.7 \pm 5.7 \mathrm{aA}$ & $85.1 \pm 6.4 \mathrm{aA}$ \\
\hline 9.0 & $5.9 \pm 4.1 \mathrm{bA}$ & $9.7 \pm 4.6 \mathrm{abA}$ & $28 \pm 12 \mathrm{aA}$ & $73.0 \pm 6.3 \mathrm{aA}$ & $74.8 \pm 3.4 \mathrm{aA}$ & $81.8 \pm 4.7 \mathrm{aA}$ \\
\hline 12.0 & $9.5 \pm 3.5 \mathrm{bB}$ & $15.1 \pm 5.1 \mathrm{bAB}$ & $26.2 \pm 2.5 \mathrm{aA}$ & $72.3 \pm 7.9 \mathrm{aA}$ & $73.6 \pm 3.5 \mathrm{aA}$ & $78.2 \pm 7.9 \mathrm{aA}$ \\
\hline 15.0 & $6.2 \pm 4.5 \mathrm{bB}$ & $11 \pm 10 \mathrm{abA}$ & $24.8 \pm 4.0 \mathrm{aA}$ & $69 \pm 10 \mathrm{aA}$ & $67.0 \pm 6.5 \mathrm{aA}$ & $74.0 \pm 4.8 \mathrm{aA}$ \\
\hline 18.0 & $6.7 \pm 5.7 \mathrm{bA}$ & $15.0 \pm 3.6 \mathrm{abA}$ & $36 \pm 15 \mathrm{aA}$ & $67.2 \pm 8.4 \mathrm{aA}$ & $74.0 \pm 2.8 \mathrm{aA}$ & $76.7 \pm 8.8 \mathrm{aA}$ \\
\hline 21.0 & $8.6 \pm 2.1 \mathrm{bB}$ & $16 \pm 11 \mathrm{abA}$ & $28.8 \pm 4.7 \mathrm{aA}$ & $67.6 \pm 8.9 \mathrm{aA}$ & $66.6 \pm 7.2 \mathrm{aA}$ & $73.7 \pm 3.9 \mathrm{aA}$ \\
\hline 24.0 & $6.7 \pm 0.9 \mathrm{bA}$ & $17.0 \pm 4.1 \mathrm{bA}$ & $29 \pm 13 \mathrm{aA}$ & $64.9 \pm 7.8 \mathrm{aA}$ & $67.9 \pm 3.4 \mathrm{aA}$ & $73.7 \pm 6.6 \mathrm{aA}$ \\
\hline
\end{tabular}

The CRRs and LRRs of TN at different times in the three treatments are shown in Table 7. Compared with those of $\mathrm{NH}_{3}-\mathrm{N}$, the $C R R s$ of $\mathrm{TN}$ in the three treatments were all relatively low. The CRRs of $\mathrm{TN}$ in $\mathrm{T} 1, \mathrm{~T} 2$ and $\mathrm{T} 3$ averaged 9.7, 14.8 and $27.4 \%$. The CRRs of TN in T1 decreased with time, whereas the CRRs of TN in T2 and T3 fluctuated with time. The LRRs of TN were significantly positively linearly correlated with the increase of inflow concentration $(r=0.999$, the critical value of correlation coefficient). 


\section{Discussion}

\section{Outflow initiation and variation}

Reducing runoff volume is one of the primary ways for a VFS to reduce pollution loads. Retention efficiencies of VFSs for runoff differ largely because of the infiltration rate, vegetation condition and slope gradient. Infiltration rate is related to the soil texture, porosity, initial soil moisture and inflow rate. Sandy and high porosity soil with low initial moisture can retain more surface runoff. Inflow rate to the VFS affects the surface runoff depth and head pressure, which affect the infiltration volume. Vegetation condition and slope gradient influence the runoff velocity that prolongs hydraulic retention time. According to current research, VFSs established in the field can reduce surface runoff more than $50 \%[35,36]$, and wide and flat grass VFSs can reduce surface runoff more than $90 \%$ $[12,37,38]$. In this study, the inflow rates to the Bermuda VFS were calibrated and ranged from 0.195 to $0.210 \mathrm{dm}^{3} / \mathrm{s}$, and the initial soil moisture content was artificially controlled at $37.0 \pm 3.9 \%$. The RRRs of the Bermuda VFS reached from 73.1 to $86.1 \%$ in each trial. The high retention efficiency depended on the flourishing plants with intricate systems of roots and stems.

Figure 4 shows that the outflow rates in the three treatments increased and display significant positive linear correlations with time. This response was related to the variation of infiltration rate of the surface runoff. Generally, infiltration rate will decrease with time to a constant situation after runoff occurs. Double-ring infiltration tests on site showed that it took approximately $20 \mathrm{~min}$ for the infiltration rate to start to maintain a constant situation $(33.12 \mathrm{~mm} / \mathrm{h})$. Each trial lasted approximately $24 \mathrm{~min}$ after outflow initiation, and the infiltration rate decreased to constant situation. Consequently, the outflow rates increased with time.

\section{Mechanisms of VFS in reducing nitrogen}

Many $\mathrm{NH}_{3}-\mathrm{N}$-related physical and biochemical reactions occurs in the soil-plant interface during trials, such as infiltration, soil adsorption and desorption, plant uptake, microbe assimilation and mineralization, interflow dilution, deposition of sediment-bound $\mathrm{NH}_{3}-\mathrm{N}$, and decomposition of soil organic matter [10, 13]. But runoff infiltration, soil adsorption, plant uptake and soil microbial assimilation may be most critical for retention of $\mathrm{NH}_{3}-\mathrm{N}$ in VFSs $[39,40]$. Generally, load reduction was achieved by runoff infiltration and concentration decrease. In this study, flow measurement and concentration detection shown that the surface runoff was reduced greatly through infiltration, and the outflow concentrations for $\mathrm{NH}_{3}-\mathrm{N}$ was much lower than inflow concentrations. Therefore, infiltration reduced runoff volume, and soil adsorption, plant uptake and soil microbial assimilation in the soil-plant interface reduced the $\mathrm{NH}_{3}-\mathrm{N}$ concentration of outflow runoff. $\mathrm{NH}_{3}-\mathrm{N}$ is small molecule of nitrogen with positive charges and therefore can be easily adsorbed by soil colloids and soil humus with negative charges, in addition to uptake by plants and assimilation by microbes [41, 42]. The concentration reduction of $\mathrm{NH}_{3}-\mathrm{N}$ occurred in and above soil-plant interface of the Bermuda VFS. During trials, the soil-plant interface was covered with 3-5 cm humus and litter layer with large superficial area, and could contact the shallow runoff sufficiently. The Bermuda stolon aboveground account for a small portion of total biomass of plant and only pick up the contactable $\mathrm{NH}_{3}-\mathrm{N}$ molecule 
of surface runoff. The microbes in soil-plant interface could hardly assimilate the $\mathrm{NH}_{3}-\mathrm{N}$ in short time because of small biomass.

Soil adsorption rate and capacity increases with the increase of $\mathrm{NH}_{3}-\mathrm{N}$ concentration [40]. When soil was waterlogged in constant $\mathrm{NH}_{3}-\mathrm{N}$ concentration, soil adsorption rate will decease with time before dynamic balance. The higher the $\mathrm{NH}_{3}-\mathrm{N}$ concentration is, the more significantly the adsorption rate decreases [43]. The mechanisms above explain the changes of the outflow concentrations of $\mathrm{NH}_{3}-\mathrm{N}$ in Figure 3.

The retention of $\mathrm{NO}_{3}-\mathrm{N}$ in VFSs is primarily achieved by runoff infiltration, plant uptake and soil microbial processes [39, 40]. Soil adsorption to $\mathrm{NO}_{3}-\mathrm{N}$ molecules is extremely weak. Similar to retention of $\mathrm{NH}_{3}-\mathrm{N}$ in this study, infiltration reduced the runoff volume, and plant uptake and soil microbial processes reduced the $\mathrm{NO}_{3}-\mathrm{N}$ concentration. The transformation of $\mathrm{NO}_{3}-\mathrm{N}$ requires particular soil redox conditions [44]. Each trial duration was approximately 30 minutes with a 3 hour interval; thus, forming anaerobic environment would be difficult. Denitrification were likely repressed throughout the experiment [45]. Therefore, we surmise that the reduction in concentration of $\mathrm{NO}_{3}-\mathrm{N}$ was primarily the result of plant uptake and soil microbe assimilation. Consequently, the CRRs of $\mathrm{NO}_{3}-\mathrm{N}$ were substantially lower than those of $\mathrm{NH}_{3}-\mathrm{N}$ [46].

\section{Nitrogen export and optimal inflow concentration}

Soil adsorption played more important roles in reducing $\mathrm{NH}_{3}-\mathrm{N}$ concentration. Soil adsorption and desorption was influenced by $\mathrm{NH}_{3}-\mathrm{N}$ concentration to great extent. Generally, Low concentration was unconducive to soil adsorption. High inflow concentration may exceed the soil adsorption rates and lead to a low CRRs. In this study, the VFS can reduce the $\mathrm{NH}_{3}-\mathrm{N}$ concentration of runoff efficiently. The average CRRs of $\mathrm{NH}_{3}-\mathrm{N}$ in $\mathrm{T} 1, \mathrm{~T} 2$ and $\mathrm{T} 3$ were $79.5,90.3$ and $66.1 \%$, and the average LRRs were 93.7, 96.7 and $90.0 \%$, respectively, which mean the appropriateness of the inflow concentrations of $\mathrm{NH}_{3}-\mathrm{N}$ in this study. The tendency and changes of the CRRs of $\mathrm{NH}_{3}-\mathrm{N}$ with the inflow concentrations showed that the inflow concentration of $\mathrm{NH}_{3}-\mathrm{N}$ had a critical value between $\mathrm{T} 1\left(0.65 \mathrm{mg} / \mathrm{dm}^{3}\right)$ and $\mathrm{T} 3\left(3.52 \mathrm{mg} / \mathrm{dm}^{3}\right)$. When the inflow concentration of $\mathrm{NH}_{3}-\mathrm{N}$ was lower than the critical value, the VFS could retain most of the $\mathrm{NH}_{3}-\mathrm{N}$ load in the runoff. By contrast, the VFS could only retain part of the $\mathrm{NH}_{3}-\mathrm{N}$ load at a concentration greater than the critical value.

Unlike $\mathrm{NH}_{3}-\mathrm{N}$, the retention efficiency of the VFS for $\mathrm{NO}_{3}-\mathrm{N}$ was relative low. The average $C R R s$ of $\mathrm{NO}_{3}-\mathrm{N}$ in $\mathrm{T} 1, \mathrm{~T} 2$ and $\mathrm{T} 3$ was $10.5,6.8$ and $14.0 \%$, respectively, fluctuating and slightly increasing with the increase of inflow concentration. Generally, low inflow concentrations are not conducive to plant uptake and soil microbe assimilation, whereas high inflow concentrations may exceed the total rate of plant uptake and soil microbe assimilation. Both too low and too high inflow concentrations can lead to low CRRs [21, 46]. The Fescue VFSs 3-21 m wide could not remove the $\mathrm{NO}_{3}-\mathrm{N}$ effectively from the feedlot runoff with as low as approximately $0.5 \mathrm{mg} / \mathrm{dm}^{3}$ of concentration [46], while as the 7.5 and $15 \mathrm{~m}$ wide mixed grass VFSs of Fescue and switchgrass reduced $\mathrm{NO}_{3}-\mathrm{N}$ in liquid swine manure by 23 and $38 \%$, respectively, when the inflow concentration was approximately $28 \mathrm{mg} / \mathrm{dm}^{3}$ [47]. In this study, the inflow concentration of $\mathrm{NO}_{3}-\mathrm{N}$ was $3.02-6.78 \mathrm{mg} / \mathrm{dm}^{3}$, which is slightly less than the inflow concentrations in previous studies. Based on above analysis, the optimal inflow concentration for the highest reduction efficiency was thus higher than that of T3 $\left(6.78 \mathrm{mg} / \mathrm{dm}^{3}\right)$. 
The retention efficiency of TN can differ largely because of VFS conditions, inflow rate and inflow concentration [48]. In this study, the CRRs of TN in T1, T2 and T3 were 9.7, 14.8 and $27.4 \%$, respectively. These values are consistent with research for Elymus dahuricus VFSs of the same width, but are a little lower than the results obtained for grass VFSs of the same width [47]. Differences in unit flow rate and inflow concentration are likely reasons for these differences. A large unit flow rate is more prone to form concentrated flow, which in addition to a lower inflow concentration, could reduce the possibility of nitrogen capture by VFSs. The tendency and changes of the CRRs of TN with the inflow concentrations showed that if the inflow concentration continued to increase (higher than T3), the CRR of TN would also increase. Despite the lower CRRs of TN, the LRRs of TN in T1, T2 and T3 averaged 72.1, 74.3 and $81.2 \%$, respectively, because of the high soil permeability, consistent with previous research.

\section{Conclusions}

Reservoir water pollution control is receiving increasing attention by society. VFSs are one of the primary ways to control non-point pollution. Field simulated runoff discharge experiments were carried out in Bermuda VFSs plot to investigate the retention efficiency and mechanisms for runoff, $\mathrm{NH}_{3}-\mathrm{N}, \mathrm{NO}_{3}-\mathrm{N}$ and $\mathrm{TN}$. The results showed that the Bermuda VFS efficiently retained runoff and the concentrations and loads of $\mathrm{NH}_{3}-\mathrm{N}, \mathrm{NO}_{3}-\mathrm{N}$ and TN. The Bermuda VFS reduced 73.1-86.1\% of surface runoff through infiltration. The CRRs of $\mathrm{NH}_{3}-\mathrm{N}, \mathrm{NO}_{3}-\mathrm{N}$ and $\mathrm{TN}$ ranged from 66.1 to $90.3 \%$, from 6.8 to $14.0 \%$ and from 9.7 to $27.4 \%$, and the LRRs ranged 90.0-96.7 \%, 72.0-77.9\% and 72.1-81.2\%, respectively. The outflow concentrations of $\mathrm{NH}_{3}-\mathrm{N}$ increased with time and with the increase of inflow concentration, whereas the CRRs and LRRs of $\mathrm{NH}_{3}-\mathrm{N}$ increased at the beginning and then decreased with the increase of inflow concentration. The inflow concentration of $\mathrm{NH}_{3}-\mathrm{N}$ had a critical value between T1 $\left(0.65 \mathrm{mg} / \mathrm{dm}^{3}\right)$ and T3 $\left(3.52 \mathrm{mg} / \mathrm{dm}^{3}\right)$; at values lower than the critical value, the retention efficiency increased with the increase of inflow concentration, and at values above critical value, retention efficiency decreased. The outflow concentrations of $\mathrm{NO}_{3}-\mathrm{N}$ remained unchanged with time. The CRRs of $\mathrm{NO}_{3}-\mathrm{N}$ increased slightly with the increase of inflow concentration. The $L R R s$ of $\mathrm{NO}_{3}-\mathrm{N}$ remained unchanged at the beginning and then increased with the increase of inflow concentration. The optimal inflow concentration of $\mathrm{NO}_{3}-\mathrm{N}$ for the optimum CRR was greater than that of T3 $\left(6.78 \mathrm{mg} / \mathrm{dm}^{3}\right)$. The outflow concentrations of TN remained almost unchanged with time. The CRRs and LRRs of TN increased with the increase of inflow concentration. The optimal inflow concentration of TN for the optimum $C R R$ was greater than that of T3 $\left(10.21 \mathrm{mg} / \mathrm{dm}^{3}\right)$. The study showed that Bermuda grass can retain nitrogen in runoff efficiently and should be promoted around the Danjiangkou reservoir.

\section{Acknowledgments}

This work was supported by The National Key R\&D Program of China (2017YFC0404502\&2017YFC0505302); The Science and Technology Promotion Program of Ministry of Water (SF-201708); The National Key Technology R\&D Program of China (2012BAC06B03). 
Retention efficiency of vegetative filter strips for nitrogen in surface runoff in Danjiangkou Reservoir ... 295

\section{References}

[1] Cai JL, Varis L, Yin H. China's water resources vulnerability: A spatio-temporal analysis during 2003-2013. J Clean Prod. 2017;142:2901-2910. DOI: 10.1016/j.jclepro.2016.10.180.

[2] Liu W, Liu L, Tong F. Least squares support vector machine for ranking solutions of multi-objective water resources allocation optimization models. Water. 2017;9:257. DOI: 10.3390/w9040257.

[3] Ding X, Chong X, Bao Z, Xue Y, Zhang S. Fuzzy comprehensive assessment method based on the entropy weight method and its application in the water environmental safety evaluation of the Heshangshan drinking water source area, Three Gorges reservoir area, China. Water. 2017;9:329. DOI:10.3390/w9050329.

[4] Hanrahan M, Jnr BD. The rocky path to source water protection: a cross-case analysis of drinking water crises in small communities in Canada. Water. 2017;9:388. DOI: 10.3390/w9060388.

[5] Ding X, Xue Y, Lin M, Jiang, G. Influence mechanisms of rainfall and terrain characteristics on total nitrogen losses from regosol. Water. 2017;9:167. DOI: 10.3390/w9030167.

[6] Alvarez S, Asci S, Vorotnikova E. Valuing the potential benefits of water quality improvements in watersheds affected by non-point source pollution. Water. 2016;8:112. DOI: 10.3390/w8040112.

[7] Xin XK, Li KF, Brian F, Yin W. Evaluation, prediction, and protection of water quality in Danjiangkou Reservoir, China. Water Sci Eng. 2015;8:30-39. DOI: 10.1016/j.wse.2014.11.001.

[8] Mekonnen M, Keesstra SD, Ritsema CJ, Stroosnijder L, Baartman JEM. Sediment trapping with indigenous vegetation types showing differences in plant traits in northwest Ethiopia. Catena. 2016;14:755-763. DOI: 10.1016/j.catena.2016.08.036.

[9] Lobo GP, Bonilla CA. A modeling approach to determining the relationship between vegetative filter strip design and sediment composition. Agric Ecosyst Environ. 2017;237:45-54. DOI: 10.1016/j.agee.2016.12.027.

[10] Olilo CO, Onyando JO, Moturi WN, Muia AW, Roegner AF, Ogari Z, et al. Composition and design of vegetative filter strips instrumental in improving water quality by mass reduction of suspended sediment, nutrients and Escherichia coli in overland flows in eastern escarpment of Mau Forest, Njoro River Watershed, Kenya. Energy Ecol Environ. 2016;1:386-407. DOI: 10.1007/s40974-016-0032-9.

[11] Dillaha TA, Sherrard JH, Lee D. Long-term effectiveness of vegetative filter strips. Water Environ Technol. 1989;1:419-421. https://vtechworks.lib.vt.edu/bitstream/handle/10919/46593/WRRC_Bull_ 153.pdf? sequence $=1$.

[12] Wilson LG. Sediment removal from flood water by grass filtration. Trans ASAE. 1967;10:35-37. DOI: $10.13031 / 2013.39587$.

[13] Naiman RJ, Decampa H. The ecology of interface: riparian zones. Ann Rev Ecol Syst. 1997;28:621-658. DOI: 10.1146/annurev.ecolsys.28.1.621.

[14] Environmental Protection Agency (EPA). National management measures to protect and restore wetlands and riparian areas for the abatement of nonpoint source pollution. In: National Management Measures to Protect and Restore Wetlands and Riparian Areas for the Abatement of Nonpoint Source Pollution. 2005, 61-80. EPA 841-B-05-003. https://www.epa.gov/nps/national-management-measures-protect-and-restorewetlands-and-riparian-areas-abatement-nonpoint.

[15] Munoz-Carpena R, Parsons JE. VFSMOD-W Vegetative filter strips modeling system: model documentation and user's manual version 6. Gainesville, FL. USA: University of Florida; 2014. https://abe.ufl.edu/faculty/carpena/files/pdf/software/vfsmod/VFSMOD_UsersManual_v6.pdf.

[16] Mohamad A, Fulazzaky Mohd HK, Badronnisa YJ. Sediment traps from synthetic construction site storm water runoff by grassed filter strip. J Hydrol. 2013; 502: 53-61. DOI: 10.1016/j.jhydrol.2013.08.019.

[17] Kuo YM, Muñoz-Carpena R. Simplified modeling of phosphorus removal by vegetative filter strips to control runoff pollution from phosphate mining areas. J Hydrol. 2009;378:343-354. DOI: $10.1016 /$ j.jhydrol.2009.09.039.

[18] Faulkner JW, Zhang W, Geohring LD, Steenhuis TS. Nutrient transport within three vegetative treatment areas receiving silage bunker runoff. $J$ Environ Manage. 2011;92:587-595. DOI: 10.1016/j.jenvman.2010.09.020.

[19] Shin J, Gil K. Environ. Effect of rainfall characteristics on removal efficiency evaluation in vegetative filter strips. Earth Sci. 2014;72:601-607. DOI: 10.1007/s12665-013-2995-6.

[20] Santin FM, Silva RVD, Grzybowski JMV. Artificial neural network ensembles and the design of performance-oriented riparian buffer strips for the filtering of nitrogen in agricultural catchments. Ecol Eng. 2016;94:493-502. DOI: 10.1016/j.ecoleng.2016.06.008.

[21] Bhattarai R, Kalita PK, Patel MK. Nitrogen and carbon dynamics in prairie vegetation strips across topographical gradients in mixed Central Iowa agroecosystems. J Environ Manage. 2009;90:1868-1876. DOI: 10.1016/j.jenvman.2008.12.010 
[22] Pérez-Suárez M, Castellano MJ, Kolka R, Asbjornsen H, Helmers M. Nitrogen and carbon dynamics in prairie vegetation strips across topographical gradients in mixed Central Iowa agroecosystems. Agric Ecosyst Environ. 2014;188:1-11. DOI: 10.1016/j.agee.2014.01.023.

[23] Carluer N, Lauvernet C, Noll D, Munoz-Carpena R. Defining context-specific scenarios to design vegetated buffer zones that limit pesticide transfer via surface runoff. Sci Total Environ. 2017;575:701-712. DOI: 10.1016/j.scitotenv.2016.09.105.

[24] Boyd PM, Baker JL, Mickelson SK, Ahmed SI. Trans. Pesticide transport with surface runoff and subsurface drainage through a vegetative filter strip. ASAE. 2003;46:675-684. DOI: 10.13031/2013.13602.

[25] Helmers MJ, Eisenhauer DE, Eisenhauer MG, Dosskey TG, Franti JM, Brothers MC. Flow pathways and sediment trapping in a field scale vegetative filter. Trans. ASAE. 2005;48:955-968. DOI: $10.13031 / 2013.18508$.

[26] Mickelson SK, Baker JL, Ahmed SI. Vegetative filter strips for reducing atrazine and sediment runoff transport. J Soil Water Conserv. 2003;58:359-367. DOI: 10.2489/jswc.58.6.359.short.

[27] Humberto BC, Gantzer CJ, Anderson SH, Alberts EE, Thompson AL. Grass barrier and vegetative filter strip effectiveness in reducing runoff, sediment, nitrogen, and phosphorus loss. Soil Sci Soc Am J. 2004;68:1670-1678. DOI: 10.2134/jeq2006.0073.

[28] Chanasyk DS, Mapfumo E, Willms W. Quantification and simulation of surface runoff from fescue grassland watersheds. Agric Water Manage. 2003;592:137-153. DOI: 10.1016/S0378-3774(02)00124-5.

[29] Magette WL, Brinsfield RB, Palmer RE, Charles R. Nutrient and sediment removal by vegetated filter strips. Trans ASAE. 1989;32:663-667. DOI: 10.13031/2013.31054.

[30] Eghball B, Gilley JE, Kramer LA, Moorman TB. Narrow grass hedge effects on phosphorus and nitrogen in runoff following manure and fertilizer application. J Soil Water Conserv. 2000;55:172-176. DOI: 10.2489/jswc.55.2.172.short.

[31] Otto S, Vianello M, Infantino A, Zanin G, Guardo AD. Effect of a full-grown vegetative filter strip on herbicide runoff: Maintaining of filter capacity over time. Chemosphere. 2008;71:74-82. DOI: 10.1016/j.chemosphere.2007.10.029.

[32] Wanyama J, Herremans K, Maetens W, Isabirye M, Kahimba F, Kimaro D, et al. Effectiveness of tropical vegetation types as sediment filters in the riparian zone of Lake Victoria. Soil Use Manage. 2012;28:409-418. DOI: 10.1111/j.1475-2743.2012.00409. x.

[33] Duan L, Huang M, Zhang L. Differences in hydrological responses for different vegetation types on a steep slope on the Loess Plateau, China. J Hydrol. 2016;537:35-366. DOI: 10.1016/j.jhydrol.2016.03.057.

[34] Xiao B, Wang QH, Wang HF, Dai QH, Wu JY. Effects of narrow grass hedges on soil and water loss on sloping lands with alfalfa (Medicago sativa L.) in Northern China. Geoderma. 2011;167-168:91-102. DOI: 10.1016/j.geoderma.2011.09.010.

[35] Dass A, Sudhishri S, Lenka NK, Patnaik US. Runoff capture through vegetative barriers and planting methodologies to reduce erosion, and improve soil moisture, fertility and crop productivity in southern Orissa, India. Nutr Cycling Agroecosyst. 2011;89:45-57. DOI: 10.1007/s10705-010-9375-3.

[36] Rankins A, Shaw Dr, Boyette M. Perennial grass filter strips for reducing herbicide losses in runoff. Weed Sci. 2001;49:647-651. DOI: 10.1614/0043-1745(2001)049[0647: PGFSFR]2.0.CO;2.

[37] Peak S, Gil K. Correlation analysis of factors affecting removal efficiency in vegetative filter strips. Environ Earth Sci. 2016;75:38. DOI: 10.1007/s12665-015-4834-4.

[38] Deska I, Mrowiec M, Ociepa E, Łacisz K. Investigation of the influence of hydrogel amendment on the retention capacities of green roofs. Ecol Chem Eng S. 2018;25:373-382. DOI: 10.1515/eces-2018-0025.

[39] Vought LB-M, Pinay G, Fuglsang A, Ruffinoni C. Structure and function of buffer strips from a water quality perspective in agriculture landscape. Landsc Urban Plann. 1995;31:323-331. DOI: 10.1016/0169-2046(94)01057-F.

[40] Bunch ND, Bernot MJ. Nitrate and ammonium uptake by natural stream sediment microbial communities in response to nutrient enrichment. Res Microb. 2012;163:137-141. DOI: 10.1016/j.resmic.2011.11.004.

[41] Yao F, Sun JB, Tang CQ, Ni WH. Kinetics of ammonium, nitrate and phosphate uptake by candidate plants used in constructed wetlands. Proc Environ Sci. 2011;10:1854-1861. DOI: 10.1016/j.proenv.2011.09.290.

[42] Barber SA. A diffusion and mass-flow concept of soil nutrient availability. Soil Sci. 1962;93:39-49. DOI: 10.1097/00010694-196201000-00007.

[43] Zhao W, Li Y, Zhao Q, Ning ZG, Zhou CF, Wang H, et al. Adsorption and desorption characteristics of ammonium in eight loams irrigated with reclaimed wastewater from intensive hogpen. Environ Earth Sci. 2013;69:41-49. DOI: 10.1007/s12665-012-1932-4.

[44] Patrick WH, Tusneem ME. Nitrogen loss from flooded soil. Ecology. 1972;53:735-737. DOI: $10.2307 / 1934793$.

[45] Knowles R. Denitrification. Ecol Bull. 1981;33:315-329. https://www.ncbi.nlm.nih.gov/pmc/ articles/pmc373209. 
[46] Chaubey I, Edwards DR, Daniel TC, Moore Jr PA, Nichols DJ. Effectiveness of vegetative filter strips in retaining surface-applied swine manure constituents. Trans ASAE. 1994;37:845-850. DOI: 10.13031/2013.28149.

[47] Schmitt TJ, Dosskey MG, Hoagland KD. Filter strip performance and processes for different vegetation, widths, and contaminants. J Environ Qual. 1999;28:1479-1489. DOI: $10.2134 /$ jeq1999.00472425002800050013x.

[48] Helmers MJ, Isenhart TM, Dosskey MG, Dabney SM, Strock JS. Buffers and vegetative filter strips. In UMRSHNC (Upper Mississippi River Sub-basin Hypoxia Nutrient Committee). Final Report: Gulf Hypoxia and Local Water Quality Concerns Workshop. ASABE. St. Joseph, Michigan, 2008; 45-58. https://lib.dr.iastate.edu/cgi/viewcontent.cgi?article=1580\&context=abe_eng_pubs. 